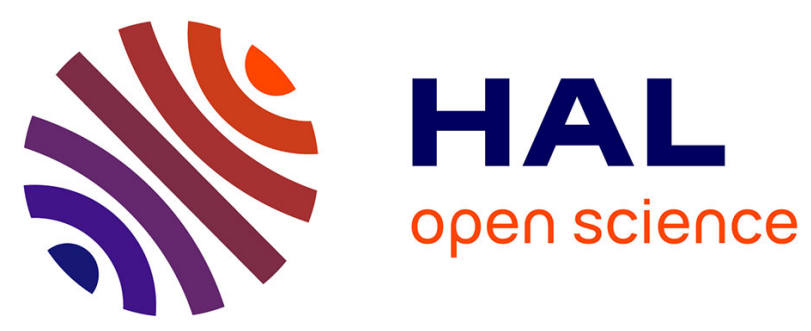

\title{
Reproductive aspects of Meloetyphlus fuscatus a meloid beetle cleptoparasite of the bee Eulaema nigrita (Hymenoptera, Apidae, Euglossini) Carlos Garófalo, Evandro Camillo, José Serrano
}

\section{- To cite this version: \\ Carlos Garófalo, Evandro Camillo, José Serrano. Reproductive aspects of Meloetyphlus fuscatus a meloid beetle cleptoparasite of the bee Eulaema nigrita (Hymenoptera, Apidae, Euglossini). Apidolo- gie, 2011, 42 (3), pp.337-348. 10.1007/s13592-011-0023-y . hal-01003554}

\section{HAL Id: hal-01003554 \\ https://hal.science/hal-01003554}

Submitted on 1 Jan 2011

HAL is a multi-disciplinary open access archive for the deposit and dissemination of scientific research documents, whether they are published or not. The documents may come from teaching and research institutions in France or abroad, or from public or private research centers.
L'archive ouverte pluridisciplinaire HAL, est destinée au dépôt et à la diffusion de documents scientifiques de niveau recherche, publiés ou non, émanant des établissements d'enseignement et de recherche français ou étrangers, des laboratoires publics ou privés. 


\title{
Reproductive aspects of Meloetyphlus fuscatus a meloid beetle cleptoparasite of the bee Eulaema nigrita (Hymenoptera, Apidae, Euglossini)
}

\author{
Carlos Alberto Garófalo, Evandro CAMILLO, José C. SERRANO \\ Departamento de Biologia, Faculdade de Filosofia, Ciências e Letras de Ribeirão Preto, USP, 14040-901, Ribeirão \\ Preto, São Paulo, Brazil
}

Received 10 January 2010 - Revised 5 June 2010 - Accepted 10 June 2010

\begin{abstract}
This study investigated the reproductive biology of the meloid beetle Meloetyphlus fuscatus Waterhouse, a cleptoparasite of Eulaema nigrita nests. New E. nigrita nests had rates of cell parasitism by meloids ranging from $3.7 \%$ to $15.8 \%$, while in re-used nests the rate of cell parasitism ranged from $1.4 \%$ to $18.7 \%$. The adult parasites were never observed trying to leave the host nests. Both sexes mated more than once. Females had a high fecundity (more than 8,000 eggs), and in most cases, deposited their eggs into the empty, old cells of the host. The triungulins (the first larval instars) hatched from eggs 18-20 days after oviposition and dispersed from the host nest by attaching themselves to males as they emerged. The triungulins most likely transfer to female bees during mating and are transported to the nests of their hosts. Within an attacked cell, the triungulin consumes the bee egg and completes its development by consuming the larval food stored in the cell.
\end{abstract}

\section{Euglossini / Eulaema / Meloidae / Meloetyphlus / cleptoparasitism}

\section{INTRODUCTION}

The Euglossini contains three free-living genera, Euglossa Latreille, 1802, Eulaema Lepeletier, 1841, and Eufriesea Cockerell, 1908, and two parasitic genera, Exaerete Hoffmannsegg, 1817 and Aglae Lepeletier and Serville, 1825 (Moure 1964, 1967; Kimsey 1987). Aglae is a monotypic genus represented by Aglae caerulea Lepeletier \& Serville, 1825, which is reported to be a cleptoparasite of Eulaema nigrita (Lepeletier, 1841) nests (Myers 1935), and species of Exaerete are known to parasitize Eulaema and Eufriesea

Corresponding author: C.A. Garófalo, garofalo@ffclrp.usp.br Manuscript editor: David Tarpy nests (Moure 1946; Dodson and Frymire 1961; Zucchi et al. 1969; Bennett 1972; Ackerman and Montalvo 1985; Roubik 1990; PereiraMartins 1991; Garófalo and Rozen 2001; Kamke et al. 2008). Besides these cleptoparasitic species, some authors have reported other insects such as meloids, rhipiphorids, leucospids, and mutillids (Ducke 1903; Bennett 1965; Dodson 1966; Roubik 1990; PereiraMartins 1991, Santos and Garófalo 1994; Nates-Parra and Gonzáles 2000; Garófalo and Rozen 2001; Cameron and Ramírez 2001; Grissell and Cameron 2002) to be parasites of the immatures or stored food from Eulaema nests.

Meloetyphlus fuscatus Waterhouse 1872 (Coleoptera: Meloidae) is the single identified species 
of meloid beetle that has been found to parasitize Eulaema nests. As observed in several other genera associated with apoid hosts, the first larval instar of $M$. fuscatus is a triungulin larva of the phoretic type (Selander 1965, 1985), and it is therefore suspected to attach itself to a host, typically a bee visiting a flower, to be phoretically carried back to its nest (Erickson et al. 1976). Although it is widely distributed with documented occurrences in Brazil (Borgmeier 1937; Pereira-Martins 1991; Santos and Garófalo 1994; Garófalo and Rozen 2001), Ecuador (Dodson 1966; Cameron and Ramírez 2001), Peru (Waterhouse 1872), Trinidad (Bennett 1965), Costa Rica (Horn 1928), and possibly Colombia (Nates-Parra and Gonzáles 2000; Nates-Parra 2005), the biology of $M$. fuscatus is not well-known. According to Selander (1985), M. fuscatus adults exhibit several specializations that allow them to adapt to life within the host nest, including the loss of eyes, functional wings, and evidence that adults do not feed (Selander 1965).

Eulaema nigrita is one of the Eulaema species with a previously documented association with M. fuscatus (Pereira-Martins 1991; Santos and Garófalo 1994; Garófalo and Rozen 2001). This species nests in preformed cavities, and the nests are established by a solitary female that dies before the emergence of her offspring. Soon after emergence, both males and females leave the nest. No males and some females return to the nest, while other females return but leave the nest within a few days of eclosion, while still others stay and re-use their natal nests. Associated females are always of the same generation and perform independent reproductive activities characterizing a communal association (Zucchi et al. 1969; PereiraMartins 1991; Pereira-Martins and Kerr 1991; Santos and Garófalo 1994; Garófalo and Rozen 2001). In this study, we present aspects of reproductive biology of $M$. fuscatus and provide new information on the nesting biology of $E$. nigrita and cell parasitism rates by its natural enemies.

\section{MATERIAL AND METHODS}

\subsection{Study area}

This study was conducted on the campus of the University of São Paulo-Ribeirão Preto $\left(21^{\circ} 05^{\prime}-\right.$ $21^{\circ} 15^{\prime} \mathrm{S}$ and $47^{\circ} 50^{\prime}-47^{\circ} 55^{\prime} \mathrm{W}$ ), State of São Paulo, Brazil, from January 1983 to March 2003. The local climate has two well-defined seasons: a cool and dry season (extending from May to August, with a mean monthly temperature ranging from $18.9^{\circ} \mathrm{C}$ to $21.8^{\circ} \mathrm{C}$ and a precipitation of 0 to $97.2 \mathrm{~mm}$ ) and a hot and wet season (extending from September to April with a mean monthly temperature ranging from $23^{\circ} \mathrm{C}$ to $25.4^{\circ} \mathrm{C}$ and a precipitation from 26 to $336.7 \mathrm{~mm}$ ).

\subsection{Methods}

To attract Eulaema females to nest in the study area, 61 circular holes were made on cement bricks that formed a wall $(11.0 \mathrm{~m}$ long and $0.7 \mathrm{~m}$ high) built in front of a small sloping earth bank (1.8 m high) near the laboratory. Each brick had two cavities with internal dimensions of $9.0 \times 10.5 \times 14.0 \mathrm{~cm}$, with holes approximately $2.0 \mathrm{~cm}$ in diameter situated $10.0,12.0$, and $22.5 \mathrm{~cm}$ above the ground.

During the study period, all nests found on the campus were recorded and were later observed every 2 to 3 days. The activity of a nest was ascertained by observing the female(s) returning from foraging flights. Six to 8 days after the females disappeared from their nests or were no longer observed performing foraging activities, the nesting site was excavated and the cell cluster and females, if present, were taken to the laboratory. In the laboratory, the cell clusters were placed in wooden boxes with inner dimensions of $19.5 \times 19.5 \times 11.5 \mathrm{~cm}$, each covered with a glass lid, a $20-\mathrm{mm}$ circular entrance hole on one side, and the bottom filled with soil. The wooden boxes were kept at room temperature $\left(21-29^{\circ} \mathrm{C}\right)$ and were observed daily until the adults emerged. After the emergence of a Eulaema female, the wooden boxes were fitted to holes in the laboratory wall. The bees were allowed to leave the boxes freely through plastic tubes connecting the boxes to the outside through holes in the laboratory wall. Observations of bee and parasite activities in the nests were made through the glass. Daily recordings were made of the 
number of individuals emerging, the number of Eulaema females working in each nest, the number of sealed cells, and the number of cells being constructed or provisioned during the re-use processes. The cell parasitism rates by M. fuscatus were estimated comparing the number of adult meloids that emerged from the cells built during the establishment of a new nest or during a re-use event with the total number of closed cells.

\subsection{Observations on the parasites}

Mating between meloids ( $n=8$ ) occurred inside the observation boxes containing the Eulaema nests with males and females that emerged from cells of the same nest $(n=3)$ or from different nests $(n=5)$. In the latter cases, the meloid female or male was transferred daily to a nest containing a male or female, respectively, at 0830 hours and was kept in the nest until 1200 hours, at which time the transferred female or male was removed to her or his natal nest. If mating occurred, the behavior of both beetles and the duration of mating were recorded, and the transferred female or male was removed to her or his nest at approximately 1700 hours. The number of eggs per egg mass deposited during each oviposition event by each meloid female was recorded by counting the number of eggs in a Petri dish. The length and maximum width of the eggs were determined from a sample of 50 eggs collected shortly after oviposition. In addition to the daily observations of the eggs left inside of the host nest, the development time of the larvae (triungulins) until hatching was determined from a sample of 30 eggs incubated in a climatic chamber at $25-27^{\circ} \mathrm{C}$.

\subsection{Dispersal of the triungulins from the host nest}

The dispersal behavior of triungulin larvae from an E. nigrita nest was observed in March and April 1991 in an observation box in the laboratory. The nest had been established inside a hollow cement brick and the female entered the hole located $22.5 \mathrm{~cm}$ above the ground. After the female disappeared from the nest, the brick was broken and the cluster of cells $(n=9)$ was taken to the laboratory and placed in an observation box. Of the nine females that emerged, eight remained in the nest and built 89 new cells. Triungulin larvae hatched from eggs laid by a meloid female that emerged from those cells. The behavior of these triungulins and their interaction with the newly emerged bees was then observed. Of the 21 males that emerged from the eclosion of the triungulins in the nest, 18 were collected as they left the nest. These males were then killed in alcohol and checked for triungulin larvae.

\section{RESULTS}

\subsection{Nesting activity of $E$. nigrita}

A total of 29 nests were found during the study period. The nesting occurred from 1989 to 1999 and in 2002, with the highest frequency observed in 1996 (Figure 1). Of the 29 nests found, 25 had been established inside hollow cement bricks and four were found inside abandoned ant nests. Aside from these new nests, 17 re-use events were observed in 11 different nests during the period from 1983 to 1986 and in 1990, 1995, 1998, 1999, and 2003 (Figure 1).

All new nests were established during the hot, wet season whereas the re-use events were observed in all months except for June and August, two of the four months of the cold and dry season. The highest nesting frequency occurred in October, while the re-use events were more uniformly distributed throughout the entire period in which re-use events were observed (Figure 2).

\subsection{Cell parasitism rates}

Of the 29 new nests found during the study period, cells from 12 nests $(41.4 \%)$ had been parasitized by meloids. There was one parasitized cell per nest in seven nests, two cells in three nests, and three cells in two nests, with parasitism rates ranging from $3.7 \%$ to $15.8 \%$. The highest frequency of nests containing parasitized cells occurred in 1996 (Figure 3). Of the five nests with more than one parasitized cell, parasites of both sexes were only found in one. In addition to the cells parasitized by 


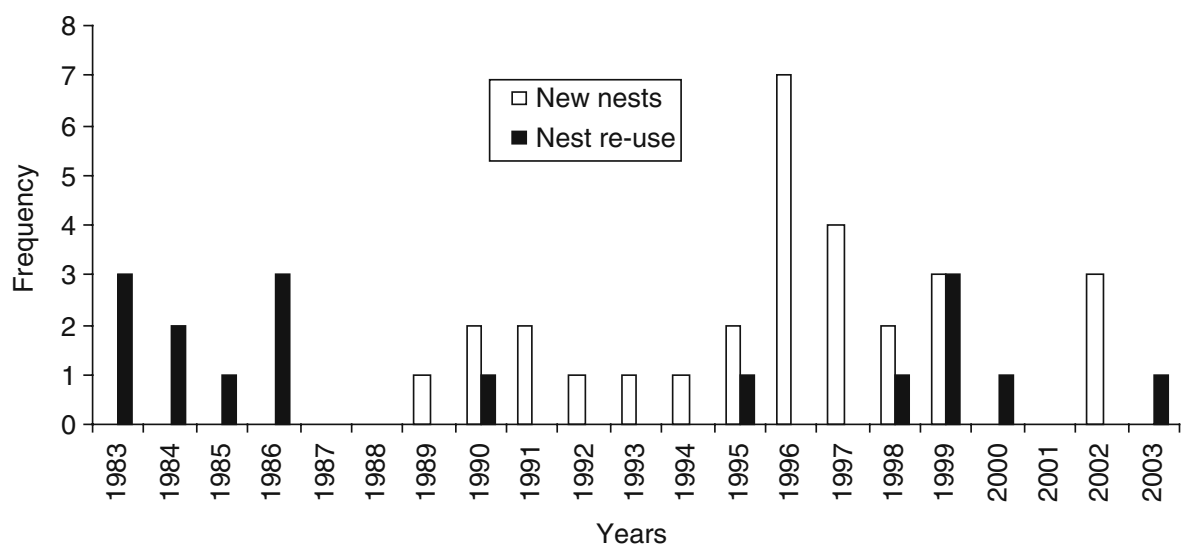

Figure 1. Number of Eulaema nigrita nesting and nest re-use events per year observed from January 1983 to March 2003 on the campus of the University of São Paulo-Ribeirão Preto, São Paulo, Brazil.

meloids, mutillids attacked cells from two nests and Exaerete smaragdina attacked one cell in one nest. In these nests, $44.4 \%$ and $53.3 \%$ of the cells were parasitized by mutillids and $10.5 \%$ of cells were parasitized by E. smaragdina. Meloids were also reared from cells provisioned during nine $(52.9 \%)$ re-use events observed in six nests (Figure 3). In these re-use events, there was one parasitized cell in five cases, two cells in two cases, and three cells in two cases. In these cases, the rates of cell parasitism per nest ranged from $1.4 \%$ to $18.7 \%$. The re-use events observed in 1983 and 1984 occurred in the same nest (Figure 3). In the first year, two meloid adults emerged from cells made during one re-use event while in the other event, one adult emerged and one dead larva was found in one cell. In the second year, one parasite emerged in each re-use event. Parasites of both sexes only emerged during two re-use events. Similar to the new nests, some cells were parasitized by E. smaragdina in three re-use events $(4.3 \%, 20.7 \%$, and $7.8 \%$ of cells parasitized), and in one event, cells were parasitized by Anthrax sp. (Diptera: Bombyliidae) as well (3.4\% of the observed parasitism).

\subsection{Emergence of parasites and adult activities}

In all new nests and re-use events that had cells parasitized by meloids, the first adult to emerge was a parasite. Only one exception was observed during a re-use event, when a male of the cleptoparasite E. smaragdina emerged 1 day before the meloid. The time that elapsed

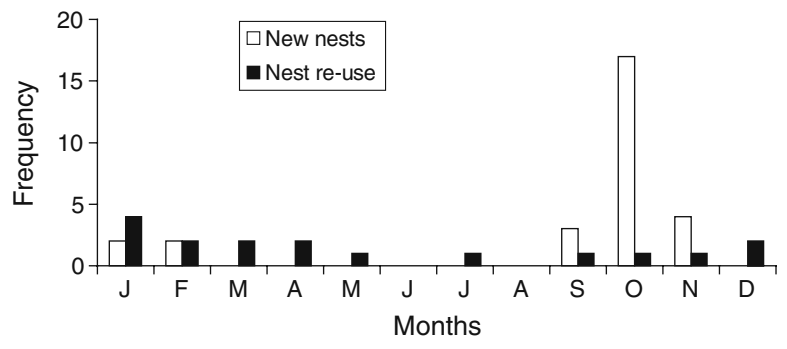

Figure 2. Number of Eulaema nigrita nesting and nest re-use events of per month observed from January 1983 to March 2003 on the campus of the University of São Paulo—Ribeirão Preto, São Paulo, Brazil. 


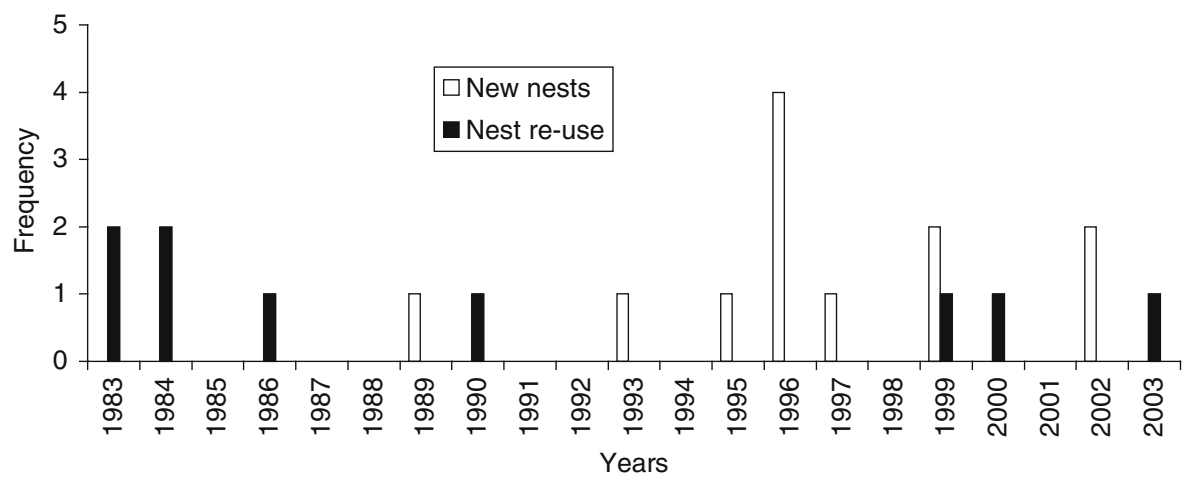

Figure 3. Number of Eulaema nigrita new nests and nest re-use events with cells parasitized by Meloetyphlus fuscatus from January 1983 to March 2003 on the campus of the University of São Paulo-Ribeirão Preto, SP, Brazil.

between the oviposition and operculation of the cell by the Eulaema female and the emergence of a parasite female ranged from 51 to 59 days (mean $=54.7 \pm 2.45$ days; $n=11$ ), and this period of time was significantly higher than that observed for the parasite male (range: 4548 days; mean $=46.3 \pm 1.03$ days; $n=6$; MannWhitney test, $Z=3.33 ; P<0.05$ ).

After emerging from the cells, either males or females walked on or around the cell cluster. If no host bee was present in the nest, the parasites remained inactive, resting at any place in the nest. When host females were present in the nest, however, the parasites usually remained hidden beneath the cells. Males and females were never seen trying to leave the nest even though the nest entrance remained open.

Males did not survive longer than females (mean $=23.3 \pm 11.4$ days; $n=6$, for males and $29.1 \pm 9.1$ days; $n=11$, for females; MannWhitney test, $Z=-1.06 ; P>0.05)$, and unmated females survived for significantly longer (mean $=33.5 \pm 10.7$ days; $n=6$ ) than mated females (23.8 \pm 1.30 days, $n=5$; Mann-Whitney test, $Z=-2.12 ; P<0.05)$.

\subsection{Mating}

Both sexes started mating when they were 2 days old and continued mating until an age of 14 days for females and 17 days for males.
When the male encountered the female (Figure 4a), he climbed onto her body from the head or side and then mounted her from behind. In that position, the male frantically moved his abdomen, attempting to insert his genitalia into that of the female while beating his fore- and midlegs on her abdominal tergites. This behavior only lasted for a few seconds, after which copulation occurred immediately. After mating began, the fore- and midlegs of the male rested on the female's abdominal tergites. The hind legs were used to grasp the female by pressing them against the sides of her abdomen near the substrate. The female remained motionless during copulation while the male occasionally moved his fore- and midlegs to try to maintain his position. At the end of copulation, the male pushed his hindlegs against the abdominal tergites of the female while withdrawing his genitalia from that of the female. Alternatively, the male turned and assumed a linear position by pushing his hindlegs against the abdominal tergites of the female. In some cases, the male also used his forelegs to finish copulation. The duration of eight matings between four females and four males ranged from 8 to 15 min (mean $=10.2 \pm$ $2.6 \mathrm{~min}$ ). Two females mated three times and two females mated only once, whereas one male mated four times, one male twice, and the other two males only once. The intervals 

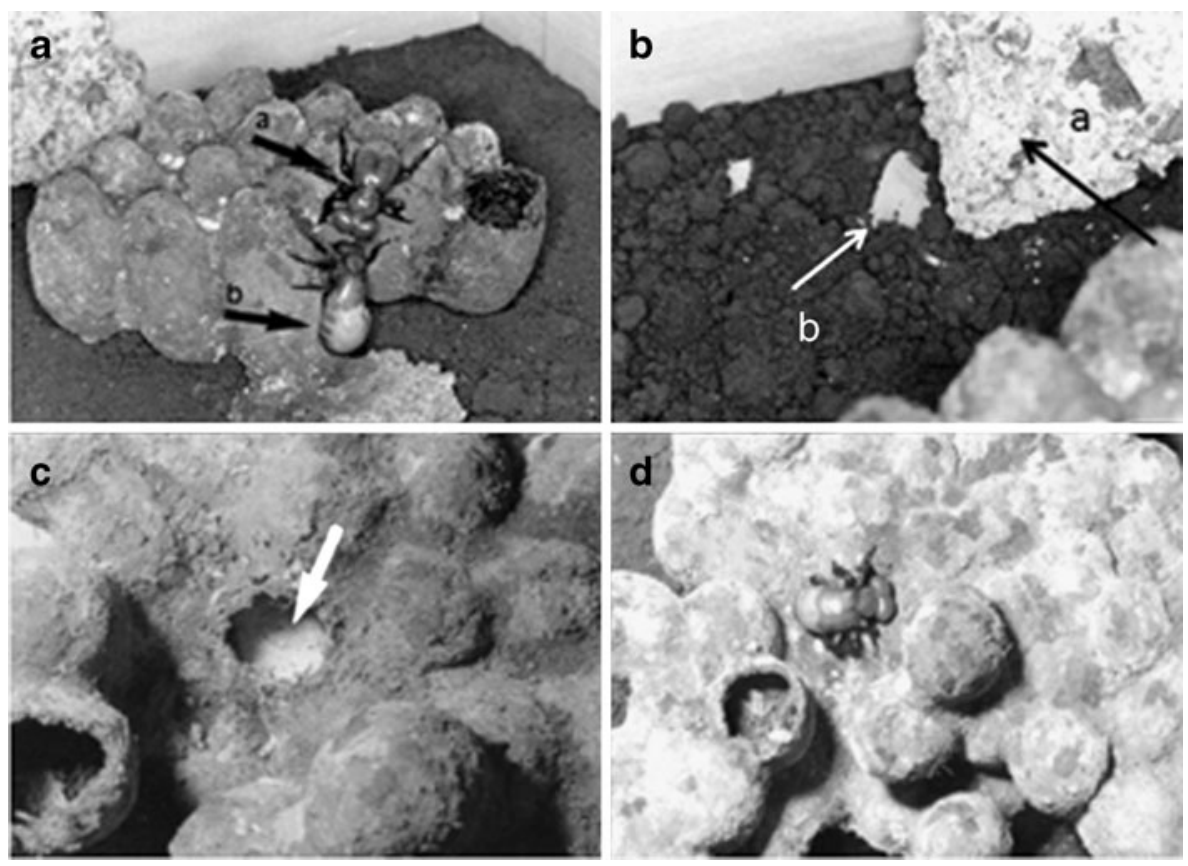

Figure 4. a Male (a) and female (b) Meloetyphlus fuscatus on the cell cluster of Eulaema nigrita. b Small stone put inside the observation box (a); egg clutch deposited under the stone (b). c Egg clutch within a host cell. d Male M. fuscatus standing on a cell in which a female oviposited.

between two successive matings for females were 2 days in two cases and 3 days in two cases, and the intervals for males were 1 day in two cases, 2 days in one case, and 3 days in one case. The females that mated three times only became receptive to males following the first or second mating after they had oviposited.

\subsection{Oviposition}

The interval between mating and oviposition was $2(n=5)$ or 3 days $(n=5)$ in females that mated three times, while the interval between two successive oviposition events by females that mated only once was $3(n=3), 4(n=2)$, or 6 days $(n=1)$.

In one case, a female deposited her eggs under a small stone placed inside the observation box to provide the bees with easy access to the exit to the field (Figure 4b). In all other cases $(n=15)$, the eggs were deposited within empty old host cells (Figure 4c). During oviposition, the eggs were placed at the bottom of the cell in an unorganized way. If a second oviposition was made in that cell, the new eggs were scattered on the eggs from the previous oviposition.

The eggs had an elongated shape and were rounded at both ends but were wider anteroapically, and they had a white color and a transparent chorion allowing the developing embryo within to be seen. The egg lengths ranged from 0.69 to $0.74 \mathrm{~mm}$ (mean $=0.71 \pm$ $0.02 \mathrm{~mm} ; n=50)$, and their maximum width ranged from 0.24 to $0.26 \mathrm{~mm}$ (mean $=0.25 \pm$ $0.01 \mathrm{~mm} ; n=50)$. The number of eggs laid in one oviposition event ranged from 1,620 to 4,734 eggs (mean=2,000.5 $\pm 1,135.5$ eggs; $n=$ 6 ), and the total number of eggs laid by two observed females were 8,407 and 8,996 . The two females each made three ovipositions and the number of eggs decreased with each oviposition. 
In the cases in which the male was present when the female oviposited, he remained in the cell where she oviposited (Figure 4d). After the female finished ovipositing, the female left the cell and walked on the cluster of the host cells. If one male was present, he walked immediately towards the female and tried to mate. If no male was present, the female could remain on the cell cluster, but when host females were present in the nest, the parasite usually remained hidden under the cells.

\subsection{Dispersal of triungulins from the host nest}

Of the 89 cells built by the eight females that shared the nest during its first re-use event, 69 cells produced E. nigrita males, seven cells produced females of the cleptoparasite Eufriesea smaragdina (Hymenoptera, Apidae), ten cells contained dead immatures, and two males and one female meloid emerged from three cells. The meloids were the first individuals to emerge, with a male emerging first followed by a female and then another male. The first male was removed from the nest and kept as a voucher specimen. The second male emerged 2 days after the female emerged and was left in the nest with her. The female made four ovipositions. The first two were made within the cell that the first meloid male emerged from, and the other two ovipositions were made in cells from which $E$. nigrita males emerged.
Brown triungulins hatched from eggs 1820 days after oviposition and most remained inside the cell during the first $24 \mathrm{~h}$ walking slowly on the mass of eggs or on the cell walls. The day after eclosion, the triungulins were quite agitated, walking quickly on all of the host's cell clusters. When the apical portion of a cell that they came across was being chewed by an individual that was just emerging or was just about to emerge, they quickly entered into the cell through the hole that was being made. As the Eulaema males took 30-55 min to complete the opening of the cell, a large number of triungulins were able to enter the cell during this time. When the male left the cell, many triungulins were seen to be attached to its body, mainly clinging to the hair of the head and thorax.

A total of 6,439 triungulins were found on 18 captured males as they were leaving the nest. The first two males to emerge were carrying $43.7 \%$ of the total number of triungulins, and the last two were carrying only $0.87 \%$ only. The decrease in the number of triungulins attached to the males was not gradual; rather their numbers were quite variable, ranging from 117 to 510 attached to the remaining males (Figure 5).

\section{DISCUSSION AND CONCLUSIONS}

E. nigrita females had previously been reported to nest in subterranean cavities, such as abandoned ant nests or within natural or artificial preexisting cavities above the ground

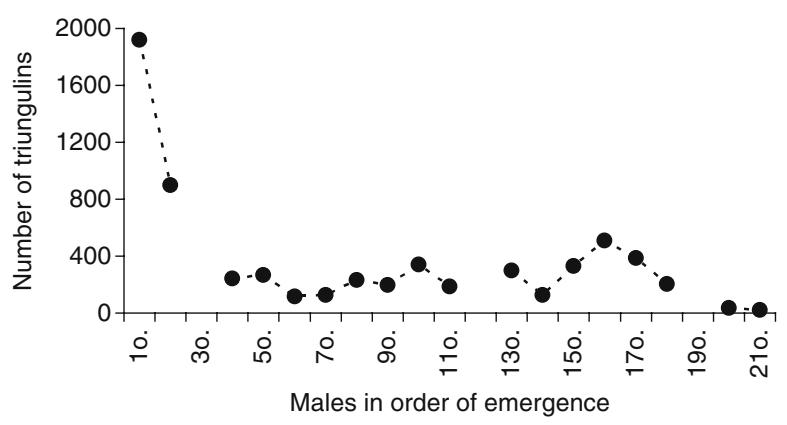

Figure 5. The number of first-instar larvae (triungulins) of Meloetyphlus fuscatus (Coleoptera: Meloidae) attached to the body of Eulaema nigrita males (Hymenoptera: Apidae) when leaving the natal nest (the third, twelfth, and ninth males were not collected). 
(Zucchi et al. 1969; Pereira-Martins and Kerr 1991; Santos and Garófalo 1994; Garófalo and Rozen 2001). In this study, females were observed to nest in hollowed cement bricks prepared to attract nesting females among other locations. The significant number of nests founded within cavities in the cement bricks shows that this kind of artificial domicile could be an important tool for future conservation efforts. Thus, in environments that are highly disturbed by humans - where the availability of natural nest cavities may be a limiting factorthe placement of artificial domiciles, such as those used in this study, could help to conserve Eulaema species in those areas.

The phenological pattern shown by E. nigrita resembles those reported for Centris analis (Vieira de Jesus 1995; Gazola and Garófalo 2003), Euglossa cordata (Garófalo 1987), and Euglossa townsendi (Augusto and Garófalo 2004), all species that occur within the same region. These patterns certainly reflect a greater availability of resources during the hot and wet season because the biotic resources used by bees (pollen and nectar) are also positively influenced by temperature and precipitation. On the other hand, similar to the reports of Garófalo (1987) for E. cordata, the reproductive activities that occurred late in the hot and wet season and during the cold and dry season were restricted to the re-use events that occurred in some nests. Under adverse climate conditions and those of low food availability, the risk of dispersion and the energetic cost required to establish a new nest must be very high. Therefore, the best survival strategy is to remain in the natal nest and to re-use the cavity.

In general, the natural enemies of bees can be divided into two groups, depending on the attack method employed: those in which adults or larvae gain access to host brood cells while the cell is being provisioned, and those in which adults attack the host immatures after the cells are sealed. Of the four enemies that attacked $E$. nigrita nests, M. fuscatus and Anthrax sp. belong to the first group, and E. smaragdina and mutillids belong to the second group. The behavioral differences displayed by these para- sites may result in different mortality rates in the attacked nests as observed in this study, with $M$. fuscatus and Anthrax sp. accounting for the lowest parasitism rates per nest. This is because parasitism by $M$. fuscatus requires that triungulin larvae find suitable hosts and are carried back to their nests. Parasitism by Anthrax sp. requires that the larvae find their own ways into the host cells because the females usually oviposit in the vicinity of the entrances of host nests (Gerling and Hermann 1976). After mutillid females enter a nest, they are able to attack all cells containing the late instar host larvae or pupae (Brothers 1989; Roubik 1990). After locating a host nest, Exaerete females return to it several times to parasitize new cells as they are completed (Garófalo and Rozen 2001). High parasitism rates by mutillids and $E$. smaragdina have been reported by Moure (1946), Zucchi et al. (1969), Roubik (1990), and Garofalo and Rozen (2001), while low parasitism rates by $M$. fuscatus were reported by Bennett (1965) for Eulaema meriana and by Dodson (1966) for Eulaema cingulata. However, parasitism by M. fuscatus has two important components: the degree of infestation of each host female by triungulin larvae and the number of females working in the nest. Thus, as suggested by Santos and Garófalo (1994), the more females in the nest and the more infested the females are, the higher the probability that the nest will become infested and the higher the percentage of parasitism of the nest. The high number of meloid adults that emerged from a nest of E. cingulata studied by Cameron and Ramírez (2001) was due to the high infestation rate of the two host adult females that were reusing the cavity.

Selander (1965) studied the morphological characteristics of adults of $M$. fuscatus and reported that they exhibited several specializations that enabled them to adapt to life within the host nest. Circumstantial evidence from that study indicated that the adults did not feed. The observation made during our study confirmed the conclusions by Selander (1965) because the adults of $M$. fuscatus were never seen trying to leave the host nests and did not consume any 
food during their entire lifespan. As consequence of these two factors, unlike most Meloidae species, M. fuscatus females deposit their eggs in the host nest, and the egg production by females and the longevity of adults depend on the food consumed during the larval stage. The increase in longevity recorded for virgin females as observed in this study may be due to egg reabsorption, a phenomenon observed for other insect species (Ramaswamy et al. 1997).

The dispersal from the host nest by phoresy, as observed in $M$. fuscatus, depends on the presence of host adults in the nest. Thus, to emerge before the hosts, as observed in this study and as described by Bennett (1965), Nates-Parra and González (2000), and Cameron and Ramirez (2001), would guarantee that dispersal would be successful. In this study, emerging before the hosts was possible because the time between the oviposition and the operculation of the cell by a host female and the emergence of the parasite was smaller than the egg-to-adult period of the host.

According to Pinto et al. (1996), courtship behavior in Nemognathinae and Tetraonycini is less elaborate and less typical of that observed in other meloids. Courtship behavior is always in a mounted position and is rarely correlated with appreciable structural modifications. We were not able to identify any courtship behavior in $M$. fuscatus because the time that elapsed between the male approaching a female and the initiation of copulation was very short. Copulation lasting some minutes and occurring with the mating pair in a dorso-ventral position, as reported in this study, are characteristics also observed in other species of Tetraonycini (Selander 1964; Bologna 1991). The occurrence of multiple matings for both sexes was also observed in Tricania stansburyi, a species of Nemognathinae (Torchio and Bosch 1992), and is also known to occur in Meloe decorus males (Meloinae; Lückmann 2005).

The reproductive parameters of $M$. fuscatus of frequency of oviposition, the interval between two successive ovipositions, the total number of eggs laid, the length and width of the eggs, and the development time of the larvae until hatching occurs are all within the observed range among of the meloid species studied.

In contrast to the data reported by Adams and Selander (1979) for the species of the Epicauta vittata group, the number of eggs laid by one female of $M$. fuscatus decreased with each oviposition event. This was observed by Lückmann and Assmann (2005) in Meloe proscarabaeus, Meloe rugosus, Meloe decorus, and Lytta vesicatoria. Although this observation may be related to the increasing age of the female as has been observed in other insect species (Adams 2000), it may also be attributed to the time interval between two successive ovipositions and the time necessary for the maturation of the egg. In addition, given that the number of eggs produced by a female is determined from the quantity and quality of food consumed only during the larval stage, the tendency is for the number of eggs to decrease as the ovipositions are made.

As previously suggested for some Meloe species (Hafernik and Saul-Gershenz 2000; Lückmann and Assmann 2005), the high fecundity shown by $M$. fuscatus must also be associated with high larval losses. These losses must occur from the beginning of the dispersal process until the triungulins arrive at a host nest where they parasitize the cells. As shown in this study, the triungulins may disperse from the host nest by attaching themselves to a host male and the presence of triungulins attached to Exaerete males collected in the field (Correia, unpublished data) suggests that the parasite can also be used by triungulins to disperse. Irrespective of the dispersal to be made trough of host males, parasites, or both, the survival and success of the triungulin in parasitizing a host cell will depend on its transportation to the host's nest. Because male bees live in the field, the triungulins carried by these bees must find a host female to be transported to her nest and to gain access to a cell that is being provisioned. This can take place during the mating process, when the triungulins are transferred from the male bee to the female bee, as reported by Hafernik and Saul-Gershenz (2000) and SaulGershenz and Millar (2006) for Meloe francis- 
canus. Similarly, the triungulins carried by Exaerete males also require access to a host nest if they are transferred to the female during mating. In this case, the triungulins will be transported by Exaerete females to the host nest and will gain access to a host cell when the attacks occur. As that parasite always attacks sealed cells (Garófalo and Rozen 2001), the triungulin will likely have to seek a being provisioned cell and stay there. After the cell is closed by the host female, the triungulin will first consume the bee egg laid there and the development is then completed by consuming the larval food (pollen + nectar) stored in the cell. In the nests where meloids of both sexes are produced, the individuals will mate and a new cycle will begin.

The observations made during this study enabled us to elucidate some aspects of the reproductive biology of $M$. fuscatus, but other factors still need to be clarified. Thus, future studies should address the following questions: Are the newly emerged females also used by triungulins to disperse from the host nest? Do the triungulins produced in a nest stay attached to females emerging from the same nest and parasitize the cells constructed by the females during the re-use of the natal nest or during the establishment of new nests? And, can the triungulins dispersed by males leave the males when they visit flowers to feed and stay on the flowers, waiting for a host female and then climbing onto her body to get carried back to her nest?

\section{ACKNOWLEDGMENTS}

This research was supported by Conselho Nacional de Desenvolvimento Científico e Tecnológico (CNPq). We are grateful to C. Costa for identifying the beetle and an anonymous referee for useful comments on the manuscript.

Aspects de la reproduction de Meloetyphlus fuscatus, un coléoptère méloïdé cleptoparasite de l'abeille Eulaema nigrita (Hymenoptera, Apidae, Euglossini)

Cleptoparasitisme / Amérique du Sud / Euglossini / Eulaema / Meloidae / reproduction / développement
Zusammenfassung - Aspekte der Reproduktion von Meloetyphlus fuscatus ein kleptoparasitischer Meloid-Käfer der Biene Eulaema nigrita (Hymenoptera, Apidae, Euglossini) In dieser Studie untersuchten wir die Fortpflanzungsbiologie von Meloetyphlus fuscatus Waterhouse, der einzige bisher identifizierte Meloid-Käfer, der Eulaema-Nester parasitiert. Die Untersuchung wurde zwischen Januar 1983 und März 2003 auf dem Campus der Universität São Paulo in Ribeirão Preto durchgeführt. Alle auf dem Campus vorkommenden EulaemaNester wurden registriert, ins Labor gebracht und dort in Beobachtungskästen mit Glasabdeckung gehalten, nachdem die Weibchen ihre Sammelaktivitäten beendet hatten. Nach dem Schlüpfen konnten die Weibchen über Bohrungen in der Laborwand ausfliegen und die Aktivitäten der Bienen und des Parasiten konnten durch die Glasabdeckung beobachtet werden. Insbesondere registrierten wir die Rate der Brutzellparasitierungen in jedem Wirtnest, die Paarungen der Käfer, die Zahl der pro Weibchen produzierten Eier, die Entwicklungszeit der Larven (Triungilinen) bis zum Schlüpfen, sowie das Verhalten und die Verbreitung der Larven aus dem Wirtsnest.

In der Untersuchungszeit wurden insgesamt 23 Nester beobachtet, mit der höchsten Nestzahl in 1996. Ausser diesen Beobachtungen konten wir von 1983 bis 1986, sowie 1990, 1995, 1998, 1999 und 2003 bei 11 Nestern insgesamt 17 Wiedernutzungsereignisse der Nester registrieren (Abb. 1). Alle neuen Nester wurden während der feuchtwarmen Monate (September bis April) angelegt, während die Wiedernutzung von Nestern in allen Monaten, ausser Juni und August erfolgte (Abb. 2). In 12 der 29 neuen Nester fanden wir von Meloiden parasitierte Brutzellen, mit Parasitierungsraten von 3,7 bis $15,8 \%$, wobei die höchsten Parasitierungsraten in 1996 beobachtet wurden (Abb. 3). Parasiten wurden auch in Zellen gefunden, die in neun Wiedernnutzungsereignissen von sechs Nestern verproviantiert worden waren (Abb. 3), und in diesen Fällen lagen die Parasitierungsraten zwischen 1,4 und 18,7\%. Die Parasiten schlüpften immer als erste (Abb. 4A). Sie verliessen nie das Wirtsnest und nahmen auch während der ganzen Zeit keine Nahrung zu sich. Paarungen der Meloiden erfolgten im Brutnest von Eulaema und beide Geschlechter paarten sich mehr als einmal. Die Weibchen hatten eine hohe Fekundität und produzierten mehr als 8.000 Eier. Diese wurden in leere alte Brutzellen abgelegt (Abb. 4C) mit Ausnahme eines Falles, bei dem das Weibchen die Eier unter einem kleinem Stein im Beobachtungskas- 
ten ablegte (Abb. 4B). Wenn ein Männchen bei der Eiablage zugegen war, blieben diese auf der Zelle mit dem Weibchen sitzen (Abb. 4D). Die braunen Triungulinen-Larven schlüpften nach 18-20 Tagen und ihre Verbreitung erfolgte, indem sie sich an geschlüpfte Bienenmännchen anhefteten (Abb. 5). Diese Triungulinen müssen während der Paarung auf Bienenweibchen übertragen werden und so Zugang zu neu angelegten und verproviantierten Brutzellen bekommen. Nachdem die Zellen verschlossen sind, fressen die Triungulinen die Bieneneier und ernähren sich bis zum Ende ihrer Entwicklung vom Larvenfutter in der Brutzelle. In Wirtsnestern, in denen sich Meloiden beiderlei Geschlechts entwickeln, kommt es zur Verpaarung und zum Beginn eines neuen Zyklus

\section{Euglossini / Eulaema / Meloidae / Meloetyphlus / Kleptoparasitismus}

\section{REFERENCES}

Ackerman, J.D., Montalvo, A.M. (1985) Longevity of euglossine bees. Biotropica 17, 79-81

Adams, T.S. (2000) Effect of diet and mating on oviposition in the twospotted stink bug Perillus bioculatus (F.) (Heteroptera: Pentatomidae). Ann. Entomol. Soc. Am. 93, 1288-1293

Adams, C.L., Selander, R.B. (1979)The biology of the blister beetles of the vittata group of the genus Epicauta (Coleoptera, Meloidae). B. Am. Mus. Nat. Hist. 162, 137-266

Augusto, S.C., Garófalo, C.A. (2004) Nesting biology and social structure of Euglossa (Euglossa) townsendi Cockerell (Hymenoptera, Apidae, Euglossini). Insectes Soc. 51, 400-409

Bennett, F.D. (1965) Notes on a nest of Eulaema terminata Smith (Hymenoptera, Apoidea) with a suggestion of the occurrence of a primitive social system. Insectes Soc. 12, 81-92

Bennett, F.D. (1972) Observations on Exaerete spp. and their hosts Eulaema terminata and Euplusia surinamensis (Hymen., Apidae, Euglossinae) in Trinidad. J.N.Y. Entomol. Soc. 80, 118-124

Bologna, M.A. (1991) Fauna d'Italia: coleoptera meloidae. Bologna, Edizioni Calderini

Borgmeier, T. (1937) Uma nova especie de Meloetyphlus Waterhouse (1872), e a hypothese da myrmecophilia deste genero (Col. Meloidae). Rev. Entomol. 7, 247255

Brothers, D.J. (1989) Alternative life-history styles of mutillid wasps (Insecta, Hymenoptera). In: Bruton, M.N. (ed.) Alternative life-history styles of animals, perspectives in vertebral science, vol. 6, pp. 279291. Kluwer Academic Publishers, Boston

Cameron, S.A., Ramírez, S. (2001) Nest architecture and nesting ecology of the orchid bee Eulaema meriana (Hymenoptera: Apinae: Euglossini). J. Kansas Entomol. Soc. 74, 142-165

De Vieira Jesus, B.M. (1995) Comportamento de nidificação e abundância sazonal de Centris (Heterocentris) analis (Fabricius, 1804)(Hymenoptera, Anthophoridae), MSc. thesis. FFCLRP-USP, Ribeirão Preto

Dodson, C.H. (1966) Ethology of some bees of the tribe Euglossini (Hymenoptera: Apidae). J. Kansas Entomol. Soc. 39, 607-629

Dodson, C.H., Frymire, G.P. (1961) Natural pollination of orchids. Mo. Bot. Gard. bull. 49, 133-152

Ducke, A. (1903) Biologische Notizen uber einige sudamerikanische Hymenoptera. Zs. Allgem. Zs. Ent. 8, 368-372

Erickson, E.H., Enns, W.R., Werner, F.G. (1976) Bionomics of the bee-associated meloidae (Coleoptera); bee and plant hosts of some neartic meloid beetles synopsis. Ann. Entomol. Soc. Am. 69, 959-970

Garófalo, C.A. (1987) Aspectos bionômicos e sociológicos de Euglossa cordata (Hymenoptera: Apidae: Euglossini), Tese de Livre-Docência, FFCLRPUSP. Ribeirão Preto, Brazil

Garófalo, C.A., Rozen Jr., J.G. (2001) Parasitic behavior of Exaerete smaragdina with descriptions of its mature oocyte and larval instars (Hymenoptera: Apidae: Euglossini). Am. Mus. Novit. 3349, $1-26$

Gazola, A.L., Garófalo, C.A. (2003) Parasitic behavior of Leucospis cayennensis Westwood (Hymenoptera: Leucospidae) and rates of parasitism in populations of Centris (Heterocentris) analis (Fabricius) (Hymenoptera: Apidae: Centridini). J. Kansas Entomol. Soc. 76, 131-142

Gerling, D., Hermann, H. (1976) The oviposition and life cycle of Anthrax tigrinus (Diptera: Bombyliidae) a parasite of carpenter bees (Hymenoptera: Xylocopidae). Entomophaga. 21, 227-233

Grissell, E.E., Cameron, S.A. (2002) A new Leucospis (Hymenoptera: Leucospidae), the first known gregarious species. J. Hymenopt. Res. 11, 271-278

Hafernik, J., Saul-Gershenz, L. (2000) Beetle larvae cooperate to mimic bees. Nature 405, 35-36

Horn, W. (1928) (Notes on Meloetyphlus fuscatus), Entomol. Blätter. 24, 88

Kamke, R., Zillikens, A., Heinle, S., Steiner, J. (2008) Natural enemies and life cycle of the orchid bee Eufriesea smaragdina (Hymenoptera: Apidae) reared from trap nests. J. Kansas Entomol. Soc. 81, 101-109

Kimsey, L.S. (1987) Generic relationships within the Euglossini (Hymenoptera: Apidae). Syst. Entomol. 12, 63-72 
Lückmann, J. (2005) The courtship behavior of Meloe decorus Brandt and Erichson and Sitaris muralis Foerster (Coleoptera: Meloidae). Coleopt. Bull. 59, $55-61$

Lückmann, J., Assmann, T. (2005) Reproductive biology and strategies of nine meloid beetles from Central Europe (Coleoptera: Meloidae). J. Nat. Hist. 39, 4101-4125

Moure, J.S. (1946) Notas sobre as mamangabas. Bol. Agric. Curitiba. 4, 21-50

Moure, J.S. (1964) A key to the parasitic euglossine bees and a new species of Exaerete from Mexico (Hymenoptera, Apoidea). Rev. Biol. Trop. 12, 15-18

Moure, J.S. (1967) A check-list of the know euglossine bees (Hymenoptera, Apidae). Atas Simpos. Biota Amazôn. 5, 395-415

Myers, J.G. (1935) Ethological observations on the citrus bee, Trigona silvestriana, and other neotropical bees. Trans. Roy. Ent. Soc. London. 83, 131-142

Nates-Parra, G. (2005) Abejas corbiculadas de Colombia. Hymenoptera: Apidae. Universidad Nacional de Colombia, Bogota D.C

Nates-Parra, G., González, V.H. (2000) Notas sobre el nido de Eulaema polychroma (Hymenoptera: Apidae: Euglossini). Actual. Biol. 22, 83-90

Pereira-Martins, S.R. (1991) Biologia de Eulaema nigrita. 2. Atividades nidais. Pap. Avuls. Zool. 37, 227-235

Pereira-Martins, S.R., Kerr, W.E. (1991) Biologia de Eulaema nigrita. 1. Construção de células, oviposição e desenvolvimento. Pap. Avuls. Zool. 37, 227235

Pinto, J.D., Bouseman, J., Bologna, M.A. (1996) Firstinstar larvae, courtship and oviposition in Electica: amending the definition of the Meloidae (Coleoptera: Tenebrionoidea). Syst. Entomol. 21, 63-74
Ramaswamy, S.B., Shu, S., Park, Y.I., Zeng, F. (1997) Dynamics of juvenile hormone-mediated gonadotropism in the Lepidoptera. Arch. Insect. Biochem. 35, 539-558

Roubik, D.W. (1990) A mixed colony of Eulaema (Hymenoptera: Apidae), natural enemies, and limits to sociality. J. Kansas Entomol. Soc. 63, 150-157

Santos, M.L., Garófalo, C.A. (1994) Nesting biology and nest re-use of Eulaema nigrita (Hymenoptera: Apidae: Euglossini). Insectes Soc. 41, 99-110

Saul-Gershenz, L.S., Millar, J.G. (2006) Phoretic nest parasites use sexual deception to obtain transport to their host's nest. PNAS 103, 14039-14044

Selander, R.B. (1964) Sexual behavior in blister beetles (Coleoptera: Meloidae). I. The genus Pyrota. Can. Entomol. 96, 1037-1082

Selander, R.B. (1965) The systematic position of Meloetyphlus, a genus of blind blister beetles (Coleoptera: Meloidae). J. Kansas Entomol. Soc. 38, 45-55

Selander, R.B. (1985) A new genus of blister beetles linking Meloetyphlus with Tetraonyx (Coleoptera: Meloidae). J. Kansas Entomol. Soc. 58, 611-619

Torchio, P.F., Bosch, J. (1992) Biology of Tricrania stansburyi, a meloid beetle cleptoparasite of the bee Osmia lignaria propinqua (Hymenoptera: Megachilidae). Ann. Entomol. Soc. Am. 85, 713-721

Waterhouse, C.O. (1872) A new genus and species of Coleoptera allied to Meloe. Entomol. Mon. Mag. 9, 31-32

Zucchi, R., Sakagami, S.F., Camargo, J.M.F. (1969) Biological observations on a tropical parasocial bee, Eulaema nigrita, with a review on the biology of Euglossinae (Hymenoptera, Apidae). A comparative study, J. Fac. Sci. Hokkaido Univ., Series IV. Zool. 17, 271-380 